\title{
POLITENESS UTTERANCES IN ENGLISH DISCUSSION
}

\author{
Elia Sapitri \\ State Institute for Islamic Studies (IAIN) Curup \\ eliasapitri07@gmail.com \\ Prihantoro \\ State Institute for Islamic Studies (IAIN) Curup \\ prihantoro@student.upi.edu \\ Sarwo Edy \\ State Institute for Islamic Studies (IAIN) Curup \\ edywong59@yahoo.co.id \\ Jumatul Hidayah \\ State Institute for Islamic Studies (IAIN) Curup \\ hidayah_jumatul@yahoo.co.id
}

\begin{abstract}
This study was conducted to investigate the types of maxims according to the principles of politeness as used by tertiary English students in the context of semi-formal discussion. This study used a descriptive qualitative method. 20 intermediate tertiary English students from one of the universities in Bengkulu were involved as the participants of this study. They were selected using a purposive sampling technique. The findings revealed that in the context of semi-formal English discussion, there were four types of maxims representing politeness. They ranged from tact maxim, generosity maxim, approbation maxim, to agreement maxim. Those maxims were realized into several uses of utterances such as requesting, asking, offering, responding, and answering. This study supports a premise that the uses of politeness maxims in English communication contribute to the success of communication per se.
\end{abstract}

Keywords: English, discussion, communication, maxims, pragmatics of politeness

\section{BACKGROUND}

In the context of speaking English communication, politeness pragmatic plays an essential role since communication is a crossing among various cultures (Barrett, Byram, Lázár, Gaillard, \& Philippou, 2014; Byram \& Wenger, 2018; Rauschert \& Byram, 2017). This type of communication dimension is in line with the status of the English language itself which is commonly dubbed as world's lingua franca (Fang, 2017; Liu \& Fang, 2017; Lu \& Hsu, 2008; Mauranen, 2018). By definition, lingua franca is the language of contact among two or more people with different mother tongues, cultural backgrounds, and/or nationalities (Jenkins, 2006; Kirkpatrick, 2018; Sherman, 2018). To prevent such conflict concerning perspective and cultural differences in communication, the mastery of politeness principles in communication is needed.

Regarding the politeness principles, Yule (1996) defined politeness in interaction as an attempt to show awareness or build consciousness of natural condition brought along by the other speaker, e.g. culture, mindset, the way of thinking, behavior, and habits that have 
been entrenched in a person. Elements embedded within one's self are cultural elements that will always become psychosocial attributes owned by the individual (Liddicoat \& Scarino, 2013). Therefore, the proficiency in communication process excideengly relies on the competency of politeness pragmatic possessed by the communicator and interlocutor. According to Leech (2011), in order to maintain the continuity of communication, both the communicator and communicant have to be able to understand the principles of politeness i.e. tact maxim, generosity maxim, approbation maxim, modesty maxim, simplicity maxim, and sympathy maxim.

If briefly synthesized, tact maxim is a principle of communication that seeks to minimize the loss of the communicant and maximize profits for the communicant. This maxim is in line with but opposing its position to the maxim of generosity. Maxim of generosity is the principle of communication that seeks to maximize losses for oneself (communicator) and minimize losses for the interlocutor (communicant). Furthermore, the principle of politeness is also realized by maxim of modesty. This is the principle of respecting the interlocutor who in the concept of the communicator will enhance appreciation and attitude of respect towards the communicant. Pair of appreciation maxim is a maxim of simplicity in which the communicator will reduce his pride and be more humble. Next, the approbation maxim. This is the principle of communication that maximizes the consensus position of the interlocutor. The maxims, in certain circumstances, are in line with maxim of sympathy that maximizes sympathy for the other speaker.

Theory related to maxims in the principle of politeness pragmatic have also been introduced by Brown and Levinson (1987). They explained that two maxims are have to be complied in order to enhance the elements of politeness in communication. The two maxims are positive and negative politeness. Maxim of positive politeness is a principle of communication that enhances provide of respect and support to interlocutor. Maxim of negative politeness is a maxim that respects and keeps the secrets of interlocutor. Furthermore, Grice (2008) also theorized about maxim of quantity and quality. Maxim of quantity is a principle that provides information needed in communication as much as possible. Maxim of quality in a principle of communication that maintain the credibility of information by discussing about things that are clear based on facts. Based on the consensus of scientists investigating the theory of the maxim, the maxim theory of Leech's version (2011) is recognized as comprehensive enough to measure the degree of politeness of a person in communication. Leech's version of the Makim theory (2011) also has a courtesy scale that is ready to be used by various researchers who are interested in the pragmatic issue of politeness.

In the context of English learning, notably in Indonesia, issues regarding pragmatic politeness is very sensitive considering the vast differences in cultural backgrounds of English students in Indonesia (Morganna, Sumardi, \& Tarjana, 2018, 2020). This is acceptable because anthropologically, Indonesia is a multicultural country (Hamied, 2012; Sukyadi, 2015). This multicultural condition will naturally bring together Indonesian students with the conflict of stereotype and the difference of cultural behaviour in communication, especially in speaking English communication. The conflict of stereotype and the difference of cultural behaviour need the communication competency in intercultural communication in which one of the indicators is to enhance the politeness pragmatic competence. 
As explained above, social condition related to English language as world's lingua franca that is spoken by all the world's population with diverse cultural backgrounds ( $\mathrm{Gu}$, 2015; Hua, 2013), the conditions of the importance of pragmatic modesty in communicating on an intercultural dimension (Byram, Gribkova, \& Starkey, 2002), and the anthropoligical conditions related to Indonesian students who are very multicultured (Hamied, 2012; Morganna et al., 2018, 2020; Sukyadi, 2015), hence research related to pragmatic discourse on politeness in English communication in the Indonesian context has very important substance. Thus, this study was designed to reveal the type of politeness pragmatic utterances used by English education students in one of the tertiary institutions in Bengkulu province.

\section{METHOD}

This study was descriptive qualitative in order to discover the data specifically based on circumstances of participant when this research was conducted (Ary, Jacobs, Sorensen, Walker \& Razavieh, 2010; Fraenkel, Wallen \& Hyun, 2012). The rationale reason behind the using of qualitative method was because the form of data in this study was an utterance. The main objective of this study was to investigate the type of utterances included in category of politeness pragmatic concerning to the context of English communication that occurred in the classroom's semi-formal discussion. This study involved 20 students as participant. They were students of English Study Program who was taking test and evaluation subject in the 6th semester. Hence, context of students' discussion that ensued during conducted this study was semi-formal discussion acted in the scope of classroom material concerning to test and its measurement.

The 20 participants involved in this study selected by purposive technique. The purposive technique is a technique which in line with ideology of constructivism as a framework of qualitative study (Creswell, 2007; Gall, Gall, \& Borg, 2003; Guba, 1981). There were several criteria that became consideration in selecting these 20 participants: first, they were students of English Study Program who have required English competence in intermediate level, consequently the data of English utterance found in their communication was English utterances which relevant to analyzed. Second, they are students who acquired good competence based on students' academic profile, consequently they were fluent to give argument in the discussion. This condition would help the researcher to recording the data of students' English utterance. Third, they were willing to participate as participant in this study.

In this research, technique of collecting data was using observation which accomplished from several discussions performance by participants. Re-observation was conducted to reach the credibility to avoid bias data. Then, the data in this research was analyzed by using interactive model as suggested by Miles, Huberman, dan Saldana (2014). There are four essential phases in analyzing the data in this research, those are: collecting data which is conducted using observation technique. The data compression accomplished by grouping technique based on themes and categories, the data in this research presented by giving example of English communication footage that is recorded during the observation in order to interpreting and discussing the data, afterward, the conclusion of the data which done by resuming the entire of findings, result of scientific interpretation, and data discussion. 


\section{FINDINGS AND DISCUSSION}

According to the data from English students' observation when they were discussing in test and assessment scope, the students' utterances showed that they used four types of maxims viewed by politeness principles of Leech (2011). Those maxims are tact, generosity, modesty, and approbation.

The first type of maxim used in discussion was wisdom maxim. The tact maxim is the politeness principles which minimized the loss and maximize the benefit of interlocutor (Leech, 2011). Based on the result of the observation, there were some utterance forms that represented the used of tact maxim, namely asking, inquiring, and offering utterances. The excerpt of communication below showed the usage of tact maxim which was recorded in conducting the observation.

Okay. I got it. But, you talked about a case of validity in your explanation. What does it mean? Would you like explain it? Please, thank you. (Participant 2)

Oh.. okay. The fourth principle of assessment is to make sure that the assessment is valid, reliable, fair, and useable. The meaning of validity here is to provide the degree of consistency of a test. The test is free from bias; it is practical in use; and it is convenient for the test purposes. (Participant 3)

According to measurement scale of maxim, the students' utterances (would you like to explain it? Please, thank you) was form of asking utterances however it was uttered as polite as possible to minimize the loss of interlocutor. This utterance was delivered when Participant 2 was asking participant 3 to repeat the explanation which had been given. The characteristics of vocabularies used also represented the high level of politeness. Participant 2 referred would to will. Would was one of expression in English which included in politeness categorization. Moreover, Participant 2 also closed the conversations with please, thank you. This phrase was increasing the politeness quality in tact maxim context.

In inquiring utterances, the utterances which consisted of tact maxim displayed on underneath communication

\section{Do you have a question about my last presentation in case I could provide a clearer outline? (Participant 9)}

Alright, I want to ask about measurement strategies to reach the degree of reliability. (Participant 13)

Based on the communication above, the style of inquiring which was questioned by Participant 9 in presenting tact maxim principle. Participant 9 added inquiring utterances in case I could provide a clear outline for minimizing the loss of interlocutor. He was concept the situation like there was a speaker who was questioning about the loss of presentation which was the disadvantage of presentation that he thought it did not complete. However, it did not happen because of speaker's disadvantages which did not comprehend the material that had been presented.

In offering context, the usage of the utterances which are consisted tact maxim shown in this communication below. 
Would you like to join me to be the moderator of my presentation? (Participant 15)

\author{
Sure, I would (Participant 7)
}

The communication above was occurred when participant 15 wanted to present the material in class discussion. At that time, there was a member of group was absent as the result he/she was offering one of his/her friends to be a moderator in the presentation which would be presented. The utterance of would you like to join me to be the moderator of my presentation? was included in politeness utterances because would used than will. Completely, the offering utterances which were uttered by participant 15 did not contain any force accordingly the paradigm within it played a role as the preventing of the loss of interlocutor. The second type of maxim which was found in utterance of the classroom discussion was generosity maxim. Based on the data of observation, generosity maxim was used in offering context. The conversations below were the examples of the generosity maxim used.

Alright guys, let me read again the question asked by Santi. (Participant 20)

Thanks. (Participant 1, 12, 14)

According to the excerpt of conversations above, the utterances of let me read again the question asked by Santi presented the generosity of participant 20 to assist rereading the question that delivered by one of her friends which had been inquired before. The purpose of rereading was to keep the discussion scope still in line with the issue.

The third type of maxim which was used by English students in classroom discussion was maxim modesty. Modesty maxim is a principle to appreciate the interlocutor in which the communicator's concept will enhance the respectful and appreciation on communicator (Leech, 2011). Modesty maxim used in responding context. The excerpt conversation below showed the usage of modesty maxim.

Let me help answer your question about the difference between validity and reliability. Validity means the accuracy of a test content aligned with the purpose, the examined materials, and representative competences which are assigned. For reliability, it refers to the extent of test consistence in which a test is considered valid if it is capable of generating scores that are sufficiently homogenous across different times and spaces. (Participant 16)

Thank you very much for the answer. You've given me a clear outline. (Participant 19)

According to the excerpt of the above communication, participant 19 provided gratitude response to appreciate the answer given by participant 16 . The gratitude response uttered was also complemented with phrase (very much) that visualized high appreciation for the answers to questions that have been given.

The fourth type of maxim examined in the discussion is approbation maxim. This is a communication principle that maximizes the position of approbation towards interlocutor 
(Leech, 2011). Based on the observation data, approbation maxim is used in utterances of providing responses and answers.

Measurements concerning validity and reliability are really important to be done towards a test before it is used to solicit students' scores. If both validity and reliability aspects are not examined in prior, the test result will not generate scores representing students' real competences. (Participant 14)

\section{I couldn't agree more with you. (Participant 6)}

Based on the above communication excerpt, participant 6's utterance (I couldn't agree more with you) is a style of English language that is usually uttered to show agreement on the highest level. Usually, this type of utterance is spoken when a person is about to show that he or she $100 \%$ agrees with the interlocutor.

Approbation maxim can also be seen in the utterances of giving answers that visualize the intent of the agreement such as the following communication examination.

Reducing bias during a test construction is a must. How about you? (Participant 12)

Yes, it is. (Participant 8)

Utterances provided by participant 8 (yes, it is) answers the question asked by participant 12. The answer was provided briefly in order to show that participant 8 agrees with participant 12 ' previous statement.

When viewed from a politeness pragmatic perspective by Leech (2011) that is theorized into six types of maxim, the data of this study present uses of four types of maxim i.e. tact maxim, generosity maxim, modesty maxim, and approbation maxim. The use of the maxims was presented in various utterances such as asking, inquiring, giving responses, and providing answers.

When interpreted, the limitation of type 7 maxim used by participants in this study was influenced by two contexts. The first context was a type of communication limited in semi formal discussion, and the second one was a communication discourse limited by the scope of topic concerning test and its measurement.

In English speaking communication that is framed by other larger discourses, the use of the entire all types of politeness maxims will be better described. This study reveals that the politeness principles implemented in communication support the course of communication. From the perspective of communication science, in particular English speaking communication which exists in intercultural communication dimension, politeness pragmatic principle was needed in order to avoid perspectives conflict in communication (Byram et al., 2002; Hua, 2013). This politeness perspective is included in the category of enhancing awareness of diversity (Xerri, 2016). Scientists concerned on examining English speaking communication, especially in the context of English language communication as world's lingua franca or international language agree that learning about politeness pragmatic is one of the steps to enhance intercultural communication competency (Badrkoohi, 2018; Byram \& Wenger, 2018; Galante, 2015; Ghasemi, Ahmadian, Yazdani, \& Amerian, 2020; Inkaew, 2016; Kusumaningputri \& Widodo, 2018; Leggett, 2014; LópezRocha, 2016; Tran \& Seepho, 2017). 


\section{CONCLUSION}

This study illustrates that in the context of semi-formal discussions using English conducted by English students at an intermediate level, there are four types of maxims that represent pragmatic courtesy. These maxims are tact maxim, generosity maxim, modesty maxim, and approbation maxim. The tact maxim is used when English students use the utterance of asking, asking, and offering. Generosity maxims are used when they use offer utterances. Modesty maxim are realized when they use the utterance of responding. The approbation maxim is used when they use the utterance of giving responses and the utterance of giving answers. This study implies that the use of politeness maxim in English communication contributes to the smooth communication.

\section{REFERENCES}

Ary, D., Jacobs, L. C., Sorensen, C. K., Walker, D. A., \& Razavieh, A. (2010). Introduction to research in education. Measurement (8th ed., Vol. 4). USA: Wadsworth, Cengage Learning. https://doi.org/10.1017/CBO9781107415324.004

Badrkoohi, A. (2018). The relationship between demotivation and intercultural communicative competence. Cogent Education, 5(1), 1-14. https://doi.org/10.1080/2331186X.2 018.1531741

Barrett, M., Byram, M., Lázár, I., Gaillard, M. P., \& Philippou, S. (2014). Developing intercultural competence through education. (J. Huber \& C. Reynolds, Eds.) (Vol. 1). Council of Europe Publishing. F67075 Strasbourg Cedex.

Brown, P., \& Levinson, S. (1987). Politeness: Some Universals in Language Usage. UK: Cambridge University Press.

Byram, M., Gribkova, B., \& Starkey, H. (2002). Developing the intercultural dimension in language teaching: A practical introduction for teachers. Strasbourg: The Council of Europe.

Byram, M., \& Wenger, M. (2018). Making a difference: Language teaching for intercultural and international dialogue. Foreign Language Annals, (December 2017), 1-12. https://doi.org/10.1111/flan.12319

Creswell, J. W. (2007). Qualitative inquiry \& research design: Choosing among five approaches (2nd ed.). USA: SAGE publications, Inc.

Fang, F. G. (2017). World Englishes or English as a Lingua Franca: Where does English in China stand? English Today, 33(1), 19-24. https://doi.org/10.1017/S0266078415000668

Fraenkel, J. R., Wallen, N. E., \& Hyun, H. H. (2012). How to design and evaluate research in education. 1221 Avenue of the Americas, New York, NY 10020: McGraw-Hill Companies, Inc. https://doi.org/10.1017/CBO9781107415324.004

Galante, A. (2015). Intercultural communicative competence in English language teaching: Towards validation of student identity. Brazilian English Language Journal, 6(1), 29-39. https://doi.org/10.15448/2178-3640.2015.1.20188

Gall, M. D., Gall, J. P., \& Borg, W. R. (2003). Educational research: An introduction (7th ed.). USA: Allyn and Bacon.

Ghasemi, A. A., Ahmadian, M., Yazdani, H., \& Amerian, M. (2020). Towards a Model of Intercultural Communicative Competence in Iranian EFL Context : Testing the Role of International Posture, Ideal L2 Self, L2 Self- Confidence, and Metacognitive 
Strategies. Journal of Intercultural Communication Research, 1-20. https://doi.org/10.1080/17475759.2019.1705877

Grice, H. . (2008). Logic and conversation. USA: University of California, Berkeley.

$\mathrm{Gu}, \mathrm{X}$. (2015). Assessment of intercultural communicative competence in FL education : A survey on EFL teachers' perception and practice in China. Language and Intercultural Communication, 1-20. https://doi.org/10.1080/14708477.2015.1083575

Guba, E. G. (1981). Criteria for assessing the trustworthiness of naturalistic inquiries. Educational Communication and Technology, 29(2), 75-91. https://doi.org/10.1007/bf02766777

Hamied, F. A. (2012). English in Multicultural and Multilingual Indonesian Education. Multilingual Education, 1(English as an International Language in Asia: Implications for Language Education), 63-78. https://doi.org/10.1007/978-94-007-4578-0_5

Hua, Z. (2013). Exploring Intercultural Communication. Exploring Intercultural Communication: Language in Action. https://doi.org/10.4324/9780203798539

Inkaew, M. (2016). An analysis of intercultural communicative competence: Hotel front office personnel in Bangkok. PASAA, 51, 185-214.

Jenkins, J. (2006). Current perspectives on teaching world Englishes and English as a lingua franca. TESOL Quarterly, 40(1), 157. https://doi.org/10.2307/40264515

Kirkpatrick, A. (2018). The development of English as a lingua franca in ASEAN. In J. Jenkins, W. Baker, \& M. Dewey (Eds.), The Routledge Handbook of English as a Lingua Franca (pp. 138-150). New York: Routlage.

Kusumaningputri, R., \& Widodo, H. P. (2018). Promoting Indonesian university students' critical intercultural awareness in tertiary EAL classrooms: The use of digital photograph-mediated intercultural tasks. System, 72, 49-61. https://doi.org/10.1016/j.system.2017.10.003

Leech, G. (2011). Prinsip-Prinsip Pragmatik (Terjemahan dalam Bahasa Indonesia). Jakarta: Universitas Indonesia.

Leggett, D. (2014). How to Develop Teachers' Intercultural Communicative Competence in the 21 st Century Education. ASILE 2014 Conference, 1-6.

Liddicoat, A. J., \& Scarino, A. (2013). Intercultural language teaching and learning. West Sussex, UK: Wiley-Blackwell.

Liu, J., \& Fang, F. (Gabriel). (2017). Perceptions, awareness and perceived effects of home culture on intercultural communication: Perspectives of university students in China. System, 67, 25-37. https://doi.org/10.1016/j.system.2017.04.003

López-Rocha, S. (2016). Intercultural communicative competence: creating awareness and promoting skills in the language classroom. In C. Goria, O. Speicher, \& S. Stollhans (Eds.), Innovative language teaching and learning at university: enhancing participation and collaboration (pp. 105-111).

Lu, Y., \& Hsu, C.-F. (Sandy). (2008). Willingness to Communicate in Intercultural Interactions between Chinese and Americans. Journal of Intercultural Communication Research, 37(2), 75-88. https://doi.org/10.1080/17475750802533356

Mauranen, A. (2018). Conceptualising ELF. In J. Jenkins, W. Baker, \& D. Martin (Eds.), The Routledge Handbook of English as a Lingua Franca (pp. 7-24). New York: Routlage. 
Miles, M. B., Huberman, A. M., \& Saldana, J. (2014). Qualitative data analysis: A methods sourcebook. Thousand Oaks, California 91320: SAGE Publications, I

Morganna, R., Sumardi, \& Tarjana, S. S. (2018). Immersion vs. construction: The portrayals of culture in Indonesian EFL learning paradigm. Journal of Language and Linguistic Studies, 14(2), 283-304. Retrieved from https://www.jlls.org/index.php/jlls/article/view/969/385

Morganna, R., Sumardi, \& Tarjana, S. S. (2020). Tertiary English students' attitudes towards intercultural language learning. Indonesian Journal of Applied Linguistics, 9(3), 657-665. https://doi.org/10.17509/ ijal.v9i3.23216

Rauschert, P., \& Byram, M. (2017). Service learning and intercultural citizenship in foreignlanguage education. Cambridge Journal of Education, (July), 1-17. https://doi.org/10.1080/0305764X.2017.1337722

Sherman, T. (2018). ELF and the EU/wider Europe. In J. Jenkins, W. Baker, \& M. Dewey (Eds.), The Routledge Handbook of English as a Lingua Franca (pp. 115-125). New York: Routlage.

Sukyadi, D. (2015). The teaching of English at secondary schools in Indonesia. Secondary School English Education in Asia: From Policy to Practice, 123-147.

Tran, T. Q., \& Seepho, S. (2017). Intercultural language education : Supportive factors and constraints on EFL learners' intercultural communicative competence development. Suranaree J. Soc. Sci, 11(1), 1-28.

Xerri, D. (2016). Teaching and learning English in a multicultural classroom: strategies and opportunities. Journal for Multicultural Education, 10(1), 19-32. https://doi.org/10.1108/JME-04-2015-0012

Yule, G. (1996). Pragmatics. New York: Oxford University Press. 